\title{
Determination of Ammonium Ion Using a Reagentless Amperometric Biosensor Based on Immobilized Alanine Dehydrogenase
}

\author{
Ling Ling Tan ${ }^{1}$, Ahmad Musa ${ }^{2}$ and Yook Heng Lee ${ }^{1, *}$ \\ 1 School of Chemical Sciences and Food Technology, Faculty of Science and Technology, \\ Universiti Kebangsaan Malaysia, Bangi, Selangor 43600, Malaysia; \\ E-Mail: babybabeoo@gmail.com \\ 2 Faculty of Science and Technology, Universiti Sains Islam Malaysia, Bandar Baru Nilai, Nilai, \\ Negeri Sembilan D.K. 71800, Malaysia; E-Mail: andong@usim.edu.my \\ * Author to whom correspondence should be addressed; E-Mail: leeyookheng@ yahoo.co.uk; \\ Tel.: +60-3-8921-3356; Fax: +60-3-8921-5410.
}

Received: 14 July 2011; in revised form: 14 August 2011 / Accepted: 5 September 2011 / Published: 29 September 2011

\begin{abstract}
The use of the enzyme alanine dehydrogenase (AlaDH) for the determination of ammonium ion $\left(\mathrm{NH}_{4}^{+}\right)$usually requires the addition of pyruvate substrate and reduced nicotinamide adenine dinucleotide (NADH) simultaneously to effect the reaction. This addition of reagents is inconvenient when an enzyme biosensor based on AlaDH is used. To resolve the problem, a novel reagentless amperometric biosensor using a stacked methacrylic membrane system coated onto a screen-printed carbon paste electrode (SPE) for $\mathrm{NH}_{4}{ }^{+}$ion determination is described. A mixture of pyruvate and NADH was immobilized in low molecular weight poly(2-hydroxyethyl methacrylate) (pHEMA) membrane, which was then deposited over a photocured pHEMA membrane (photoHEMA) containing alanine dehydrogenase (AlaDH) enzyme. Due to the enzymatic reaction of $\mathrm{AlaDH}$ and the pyruvate substrate, $\mathrm{NH}_{4}{ }^{+}$was consumed in the process and thus the signal from the electrocatalytic oxidation of $\mathrm{NADH}$ at an applied potential of $+0.55 \mathrm{~V}$ was proportional to the $\mathrm{NH}_{4}{ }^{+}$ion concentration under optimal conditions. The stacked methacrylate membranes responded rapidly and linearly to changes in $\mathrm{NH}_{4}^{+}$ion concentrations between $10-100 \mathrm{mM}$, with a detection limit of $0.18 \mathrm{mM} \mathrm{NH}_{4}{ }^{+}$ion. The reproducibility of the amperometrical $\mathrm{NH}_{4}{ }^{+}$biosensor yielded low relative standard deviations between 1.4-4.9\%. The stacked membrane biosensor has been successfully
\end{abstract}


applied to the determination of $\mathrm{NH}_{4}{ }^{+}$ion in spiked river water samples without pretreatment. A good correlation was found between the analytical results for $\mathrm{NH}_{4}{ }^{+}$ obtained from the biosensor and the Nessler spectrophotometric method.

Keywords: biosensor; ammonium ion; reduced nicotinamide adenine dinucleotide; poly(2-hydroxyethyl methacrylate); alanine dehydrogenase

\section{Introduction}

The accurate measurement of $\mathrm{NH}_{4}{ }^{+}$ion in an aquatic environment is of significant interest in environmental biological studies and the environmental evaluation of water since it is known to be toxic for aquatic organisms. In this sense, several methods have been proposed, most of them involving ion chromatography [1-3], potentiometry [4,5] or flow injection systems [6-11].

Most of the ion chromatography procedures proposed for its determination involve elaborate pre-column derivatization in some kind of matrix. Mori et al. [12] described a sensitive and rapid ion chromatography method to determine $\mathrm{NH}_{4}{ }^{+}$ion in river waters. However, baseline separations of $\mathrm{NH}_{4}{ }^{+}$ from alkali and alkaline earth metal ions in water samples were non achievable. For potentiometric detection of $\mathrm{NH}_{4}{ }^{+}$ion, nonactin has been widely used as sensing material. Even though nonactin-based ion-selective electrodes show good sensitivity toward $\mathrm{NH}_{4}{ }^{+}$ion, they suffer interference from other ions such as $\mathrm{K}^{+}[13,14]$. Flow injection systems combined with spectrophotometric methods, e.g., the Berthelot reaction involving a colour change in the presence of $\mathrm{NH}_{4}{ }^{+}$ion, have very slow reaction kinetics [15], whereas fluorimetric flow injection analysis requires pretreatment of the samples with long diffusion times to avoid background interferences $[2,16]$.

Today, there is a well-recognised trend towards the simplification and miniaturisation of analytical processes [2]. An amperometry approach employing a miniaturised SPE with immobilized enzyme as tranducer considerably improves the operation cost, providing for a simple, reliable, rapid and reproducible analytical procedure. A few biosensors for the amperometric determination of $\mathrm{NH}_{4}{ }^{+}$ion employing glutamate dehydrogenase (GLDH) have been reported where the enzyme was immobilized onto the working electrode in several ways [17-19]. However, to effect the enzymic GLDH reaction, a substrate and co-factor normally needed to be introduced and this leads to an extra step during the assay of $\mathrm{NH}_{4}{ }^{+}$ion. In order to obviate the needs for external reagent treatment during measurement, which may also cause contamination of the reference electrode, we describe in this work an approach employing a stacked membranes system for the immobilization of enzyme, co-factor and also substrate that eventually leads to a reagentless biosensor for $\mathrm{NH}_{4}{ }^{+}$ion determination.

In this work, we have used alanine dehydrogenase (AlaDH) to construct a biosensor for the determination of $\mathrm{NH}_{4}{ }^{+}$ion. To our knowledge, the use of $\mathrm{AlaDH}$ in an $\mathrm{NH}_{4}{ }^{+}$ion biosensor has not been reported. The concept of the biosensor based on $\mathrm{AlaDH}$ is the reversible amination of pyruvate to L-alanine by $\mathrm{AlaDH}$ in the presence of $\mathrm{NADH}$ co-factor and $\mathrm{NH}_{4}{ }^{+}$ion (Equation (1)) [20-22]. The current generated from the electrochemical process was measured based on the oxidation of NADH (Equation (2)) whilst the enzyme redox reaction consumed $\mathrm{NH}_{4}{ }^{+}$ion in the process. Thus, the redox 
current is proportional to the $\mathrm{NH}_{4}{ }^{+}$ion concentration changes under optimal conditions at an applied potential of $+0.55 \mathrm{~V}$ :

$$
\begin{gathered}
\text { AlaDH } \\
\text { Pyruvate }+\mathrm{NADH}+\mathrm{NH}_{4}^{+} \rightarrow \mathrm{L} \text {-alanine }+\mathrm{NAD}^{+}+\mathrm{H}_{2} \mathrm{O} \\
\mathrm{NADH} \rightarrow \mathrm{NAD}^{+}+\mathrm{H}^{+}+2 \mathrm{e}^{-}
\end{gathered}
$$

To construct the stacked membrane biosensor, AlaDH enzyme was first entrapped in the photoHEMA membrane, whereby the membrane with the entrapped enzyme was formed via UV photopolymerisation of 2-hydroxylethyl methacrylate monomer. Past studies have shown that the use of photoHEMA is compatible with many enzymes without leaching problems. To further immobilize the pyruvate and $\mathrm{NADH}$, a low molecular weight poly(2-hydroxylethyl methacrylate) (pHEMA) membrane containing both of these substances was cast on top of the enzyme membrane after photocuring. The use of this second membrane allowed both pyruvate and NADH to be immobilized but their free diffusion in the membrane would also be ensured to maintain a rapid reaction rate. The biosensor was thus designed to provide a reagentless system specific for $\mathrm{NH}_{4}{ }^{+}$ion. Figure 1 represents the mechanism of the enzymic reaction involved in the developed $\mathrm{NH}_{4}{ }^{+}$ion biosensor based on a stacked membrane system.

Figure 1. The mechanism of enzymatic reaction involved in the $\mathrm{NH}_{4}{ }^{+}$biosensor based on stacked membranes.

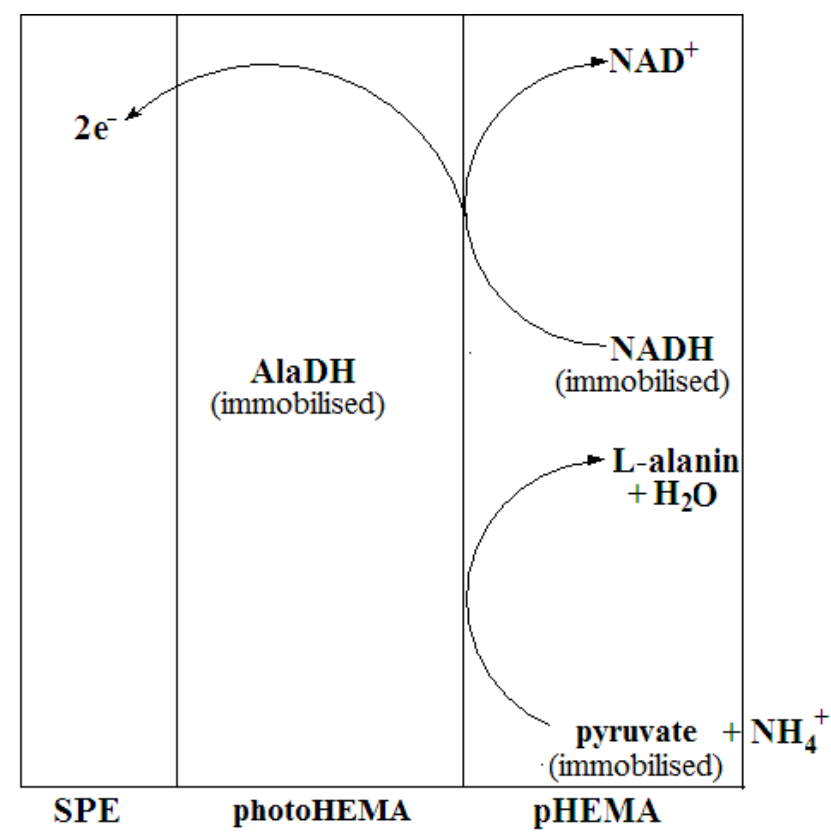

\section{Experimental}

\subsection{Reagents}

Chemicals were obtained from commercial sources and were used without further purification. $\beta$-Nicotinamide adenine dinucleotide, reduced form (NADH, 98\%) was purchased from Sigma. Stock solution of L-alanine dehydrogenase enzyme (AlaDH, E.C. 1.4.1.1, from Bacillus subtillis, Sigma) was prepared by mixing an appropriate amount of AlaDH enzyme solution with $10 \mathrm{mM}$ phosphate buffer 
pH 7 in an Eppendorf tube and stored at $4{ }^{\circ} \mathrm{C}$ [23]. Sodium pyruvate $\left(\mathrm{C}_{3} \mathrm{H}_{3} \mathrm{NaO}_{3}, 99 \%\right.$, Sigma) stock solution was prepared by dissolving an appropriate amount of pyruvate salt in deionised water. $\mathrm{pH}$ 7, $10 \mathrm{mM}$ phosphate buffer was prepared by adding $10 \mathrm{mM}$ dipotassium hydrogen phosphate $\left(\mathrm{K}_{2} \mathrm{HPO}_{4}, 98 \%\right.$, Fluka) to $10 \mathrm{mM}$ potassium dihydrogen phosphate $\left(\mathrm{KH}_{2} \mathrm{PO}_{4}, 99.5 \%\right.$, Fluka) and adjusting to the required $\mathrm{pH}$ value [23]. A standard stock ammonia solution was prepared by dissolving the required amount of concentrated ammonia solution $\left(\mathrm{NH}_{4} \mathrm{OH}, 25 \%\right.$, Merck) in deionised water. The ammonia solution used was standardised by the Nessler method using ammonium chloride $\left(\mathrm{NH}_{4} \mathrm{Cl}, 99.5 \%\right)$ salt. A homogeneous stock solution of 2-hydroxyethyl methacrylate monomer (HEMA, $\mathrm{C}\left(\mathrm{CH}_{3}\right) \mathrm{COOCH}_{2} \mathrm{CH}_{2} \mathrm{OH}, 97 \%$, Aldrich) was prepared by mixing appropriate amounts of HEMA monomer and initiator (2,2-dimethoxy-2-phenylacetophenone, DMPP, $\mathrm{C}_{16} \mathrm{H}_{16} \mathrm{O}_{3}, 98 \%$, Fluka) in a vial wrapped with aluminium foil. The mixture was then stirred gently for a few minutes and stored at $4{ }^{\circ} \mathrm{C}$. Poly(2-hydroxyethyl methacrylate) (pHEMA) was obtained commercially from Aldrich.

\subsection{Instrumentation}

Electrochemical behaviours of the reagentless biosensor were characterised using a chronoamperometry technique with an Autolab PG12 (AUT 71681) Potentiostat/Galvanostat. A conventional three-electrode electrochemical cell was used with a glassy carbon electrode as an auxiliary electrode. $\mathrm{A} \mathrm{Ag} / \mathrm{AgCl}$ electrode saturated with $\mathrm{KCl}$ was used as a reference and a modified carbon paste electrode was used as a working electrode. The SPEs used were designed by Universiti Kebangsaan Malaysia and manufactured by Scrint Print Co. All potentials were measured and reported versus a $\mathrm{Ag} / \mathrm{AgCl}$ electrode (saturated by $\mathrm{KCl}$ ). During the constant potential experiments, a magnetic stir bar was used and the background current was allowed to decay to a constant value before $\mathrm{NH}_{4}{ }^{+}$ion was added to the buffer solution. Measurements of $\mathrm{pH}$ were made with a $\mathrm{pH}$-meter (MeterLab PHM 210). AlaDH enzyme-containing photoHEMA membrane was prepared by UV-initiated photopolymerisation with an UV-exposure unit (RS Components 196-5251).

\subsection{Construction of Biosensor}

Reagentless $\mathrm{NH}_{4}{ }^{+}$biosensor was constructed by depositing $3 \mu \mathrm{L}$ of $2.98 \mathrm{mg} \mathrm{AlaDH} / \mathrm{g}$ of HEMA monomer mixture onto the SPE and exposing it to long-wave ultraviolet radiation for $500 \mathrm{~s}$ with extensive nitrogen gas purging. Next, appropriate amounts of NADH and pyruvate were dissolved into an appropriate amount of pHEMA solution prepared by dissolving $50 \mathrm{mg}$ of the polymer in $20 \%$ 1,4-dioxane in water. This was then deposited on the photocured membrane containing AlaDH enzyme and left to dry at $4{ }^{\circ} \mathrm{C}$ for $24 \mathrm{~h}$ to form the second membrane layer.

\subsection{Optimisation of Biosensor Responses}

All electrochemical experiments were performed at room temperature in an undivided three-electrode cell containing supporting electrolyte solution ( $4 \mathrm{~mL}$ of $10 \mathrm{mM}$ phosphate buffer $\mathrm{pH}$ 7) under constant stirring conditions (100 rpm). $\mathrm{NH}_{4}{ }^{+}$ion was injected at the electrode surface in the measurement cell after stabilisation of the baseline current. The measurements taken were expressed as the current difference in the absence and presence of $\mathrm{NH}_{4}{ }^{+}$ion. 
Biosensor response was studied using the cyclic voltammetry technique between $-1.00-1.00 \mathrm{~V}$ versus $\mathrm{Ag} / \mathrm{AgCl}$ at a scan rate of $0.02 \mathrm{~V} / \mathrm{s}$. The dependence of the amperometric signal on the applied potential was examined in the range of $0.45-0.65 \mathrm{~V}$ versus $\mathrm{Ag} / \mathrm{AgCl}$. The $\mathrm{pH}$ effect was studied by varying the $\mathrm{pH}$ of the electrolyte solution in the range of $\mathrm{pH} 5.8-8.0$ using $10 \mathrm{mM}$ potassium phosphate buffer. For the optimisation of enzyme loading in the photoHEMA membrane, enzyme membranes were prepared from $5 \mu \mathrm{L}$ mixtures of AlaDH and monomer HEMA (1:1) in different enzyme loadings (0.44-4.10 mgAlaDH/g photoHEMA).

Enzyme electrodes with different membrane thicknesses were prepared by changing the mixture volumes of monomer HEMA and AlaDH (1:1) in the range of 2-6 $\mu \mathrm{L}$ while the enzyme loading was kept constant at $2.98 \mathrm{mg} / \mathrm{g}$ photoHEMA. The thicknesses of the membranes were measured using a digital Vernier caliper after exposure of the sensing membranes to UV radiation.

Biosensor response to temperature changes in the $10-50{ }^{\circ} \mathrm{C}$ range was determined by varing the temperature of the electrolyte solution in a thermostatic bath. For this study, about 21 biosensors were prepared a day before and stored overnight at $4{ }^{\circ} \mathrm{C}$ before testing was performed.

For the optimisation of the respective NADH and pyruvate loadings in the pHEMA layer, various loadings of pyruvate (3.74-163.11 mg/g pHEMA) and NADH (22.98-1,149.11 mg/g pHEMA) were used. After optimisation of the experimental conditions, the effect on the reagentless biosensor's performance was investigated against different $\mathrm{NH}_{4}{ }^{+}$ion concentrations in the range of 10-600 mM.

The reproducibility of the biosensor was assessed using different biosensors and each biosensor was tested once by using $30 \mathrm{mM} \mathrm{NH}_{4}{ }^{+}$ion, whereas the repeatability of the biosensor was examined using the same biosensor tested in a concentration of $30 \mathrm{mM} \mathrm{NH}_{4}{ }^{+}$ion and five consecutive measurements were taken for every biosensor.

The shelf life of the biosensor was examined by determining $30 \mathrm{mM} \mathrm{NH}_{4}{ }^{+}$ion over a period of 30 days. All of the electrodes were tested once on the first day and kept at $4{ }^{\circ} \mathrm{C}$ while not in use. After that, each of these biosensors was tested twice only according to a specified date.

Interferences with the $\mathrm{NH}_{4}{ }^{+}$ion biosensor were investigated by using interferents such as $\mathrm{Na}^{+}, \mathrm{K}^{+}$, methylamine $\left(\mathrm{CH}_{3} \mathrm{NH}_{2}\right)$ and ethylamine $\left(\mathrm{C}_{2} \mathrm{H}_{5} \mathrm{NH}_{2}\right)$. The molar ratio of interferents to $\mathrm{NH}_{4}{ }^{+}$ion was varied in the range of 0.01-10. The degree of interference of these interferents was evaluated separately with amperometric measurements recorded in the presence and absence of the interferent in the determination of $30 \mathrm{mM} \mathrm{NH}_{4}{ }^{+}$ion. Statistical $t$-tests were employed to compare the responses obtained in the absence and presence of interferent.

Analysis of water samples was performed using five real water samples collected at different points along a river. Water samples presenting suspended particles were filtered through a $0.45 \mu \mathrm{m}$ cellulose acetate membrane filter (Whatman) and the $\mathrm{pH}$ was adjusted to $\mathrm{pH} 7$ using $10 \mathrm{mM} \mathrm{K}_{2} \mathrm{HPO}_{4}$ and $\mathrm{KH}_{2} \mathrm{PO}_{4}$. Recovery tests were conducted by adding standard concentrations of $\mathrm{NH}_{4}{ }^{+}$ion in the linear range to the water samples. The results were then validated using established procedure of Nesslers' method. 


\section{Results and Discussion}

\subsection{The Electrochemistry of Immobilized AlaDH}

Due to the enzymatic reaction of $\mathrm{AlaDH}$ and the pyruvate substrate, the signal from the electrocatalytic oxidation of NADH was proportional to the $\mathrm{NH}_{4}{ }^{+}$ion concentration. Figure 2 shows a typical cyclic voltammogram of the reagentless $\mathrm{NH}_{4}{ }^{+}$ion biosensor demonstrating the electrocatalytic activity of biosensor in the absence and presence of $100 \mathrm{mM} \mathrm{NH}_{4}{ }^{+}$ion. The oxidation current of the biosensor increases after $\mathrm{NH}_{4}{ }^{+}$ion addition in the positive potential region. Although no clearly defined cyclic voltammetric peak appears, the biosensor shows an increase in current in response to $\mathrm{NH}_{4}{ }^{+}$ion in the potential range of $0.4-0.9$, as indicated by the cyclic voltammogram.

Figure 2. Cyclic voltammograms of $\mathrm{NH}_{4}{ }^{+}$ion biosensor in the absence (a) and presence (b) of $100 \mathrm{mM} \mathrm{NH}_{4}{ }^{+}$ion at $\mathrm{pH} 7$ with a scan rate of $0.02 \mathrm{~V} / \mathrm{s}$ versus $\mathrm{Ag} / \mathrm{AgCl}$ electrode.

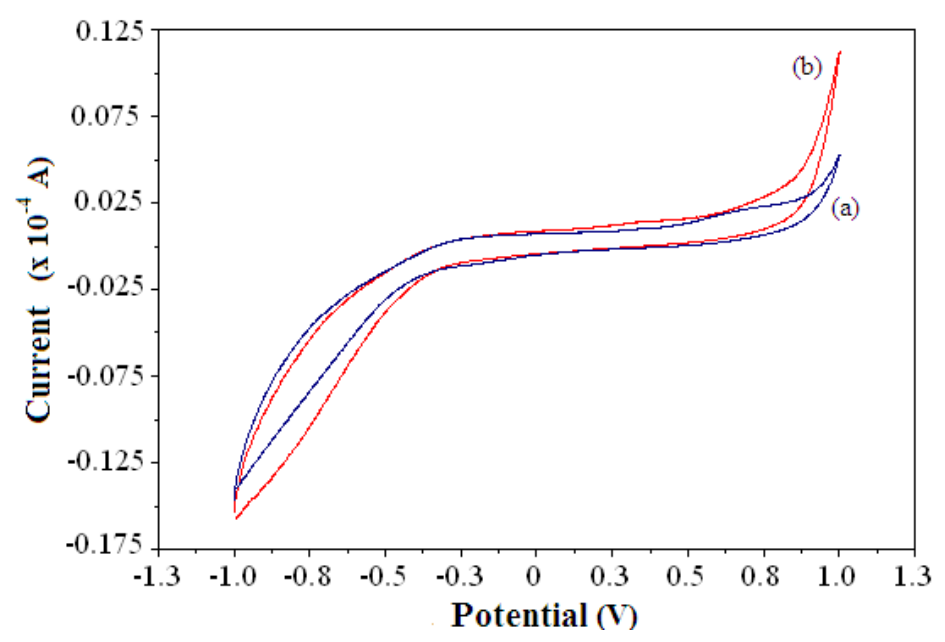

The increase of the current was attributed to the electrocatalytic oxidation of NADH during enzymatic conversion of pyruvate to L-alanine in the presence of $\mathrm{NH}_{4}{ }^{+}$ion. The electrode reaction at the electrode surface is governed by a single one-electron step in an overall two-electron process, where NADH is irreversibly oxidized through loss of an electron to produce a cation radical $\mathrm{NADH}^{\bullet}{ }^{+}$ and is expressed by Equation (3):

$$
\mathrm{NADH} \rightarrow \mathrm{NADH} \bullet+\mathrm{e}^{-}
$$

which then deprotonates to produce a neutral radical NAD• as written below:

$$
\mathrm{NADH} \bullet+\mathrm{NAD} \bullet+\mathrm{H}^{+}
$$

$\mathrm{NAD} \bullet$ is immediately oxidized to $\mathrm{NAD}^{+}$at the electrode surface at the positive potential involved as described by Equation (5):

$$
\mathrm{NAD} \bullet \rightarrow \mathrm{NAD}^{+}+\mathrm{e}^{-}
$$

The net electrochemical oxidation of NADH could be described by Equation (2) [24]:

Figure 3 shows the biosensor response of a fixed amount of $\mathrm{NH}_{4}{ }^{+}$ion when the potential was varied between $0.45-0.65 \mathrm{~V}$ and optimum applied potential was observed at $+0.55 \mathrm{~V}$, where the highest current was obtained. The working potential was found like the NADH oxidation potential using 
a 4,6-diamino-2-mercaptopyrimidine modified gold ( $\mathrm{Au}$ ) electrode [25] and a thiocytosine modified $\mathrm{Au}$ electrode [26]. However, the oxidation of $\mathrm{NADH}$ at $+0.55 \mathrm{~V}$ was found lower compared to the electrochemical oxidation of NADH employing boron-doped diamond electrode $(+0.58 \mathrm{~V})$ [27]. The potential of $+0.55 \mathrm{~V}$ was used in this work for the amperometric detection of $\mathrm{NH}_{4}{ }^{+}$ion.

Figure 3. The dependence of the bisoensor response on the applied electrode potential in a solution containing $100 \mathrm{mM} \mathrm{NH}_{4}{ }^{+}$ion at $\mathrm{pH} 7(\mathrm{n}=3)$.

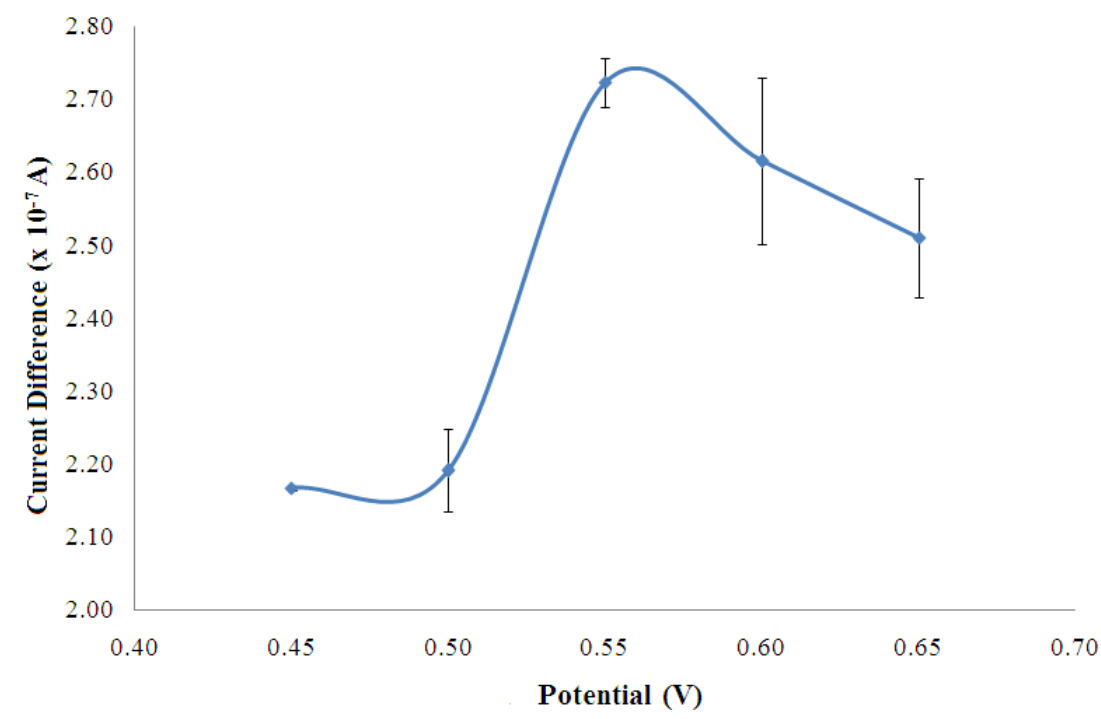

\subsection{Optimization Studies on Biosensor Operation}

\subsubsection{Optimisation of $\mathrm{pH}$}

For the optimisation of buffer $\mathrm{pH}$, as observed in Figure 4, the maximum enzyme reaction occurred at $\mathrm{pH} 7$ and it is the optimum $\mathrm{pH}$ for reversible behavior of AlaDH as reported in the literature [28].

Figure 4. The effect of $\mathrm{pH}$ on the biosensor response in a solution containing $100 \mathrm{mM}$ $\mathrm{NH}_{4}{ }^{+}$ion $(\mathrm{n}=3)$.

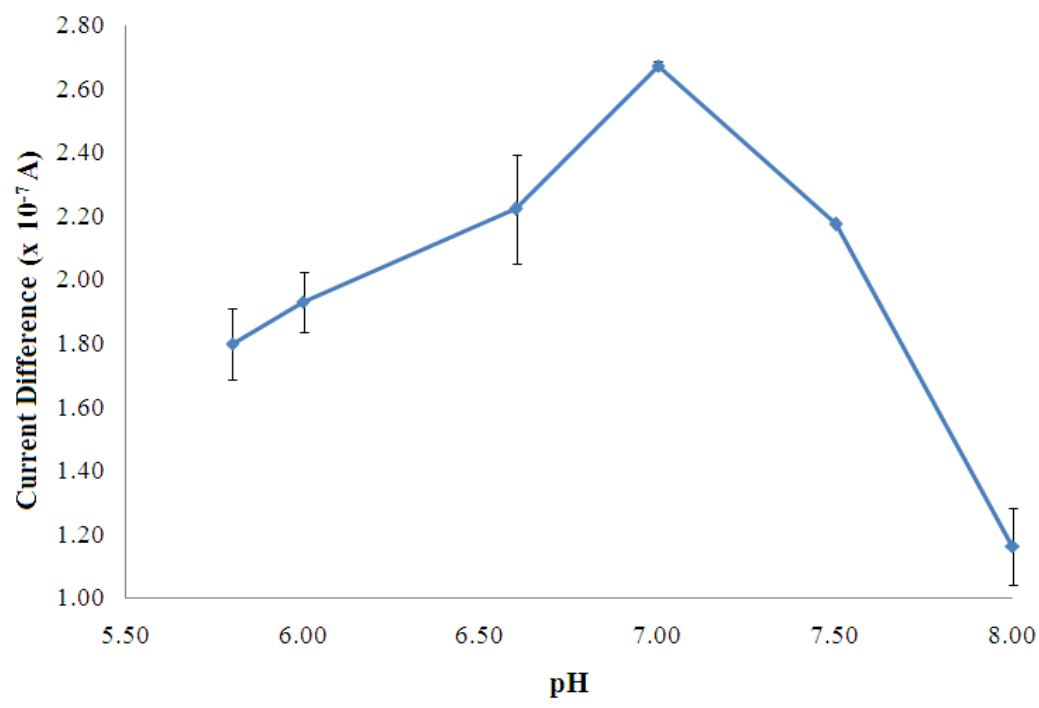


The rate of an enzyme reaction, in most cases, passes through a maximum as a function of $\mathrm{pH}$. From Figure 3, at $\mathrm{pH}$ above 7, the enzyme may undergo an irreversible denaturation where the activity may not be restored even after readjustment of the $\mathrm{pH}$ to the optimal value [29].

\subsubsection{Optimisation of Enzyme Loading for Biosensor}

The effect of enzyme loading on the biosensor response is shown in Figure 5. The response increased with increasing AlaDH enzyme loading in the membrane until saturation was achieved at an enzyme loading of $2.98 \mathrm{mg} \mathrm{AlaDH} / \mathrm{g}$ fotoHEMA. However, the response was lower after this optimal loading.

Figure 5. Effect of enzyme loading on biosensor response in a solution containing $100 \mathrm{mM}$ $\mathrm{NH}_{4}{ }^{+}$ion at $\mathrm{pH} 7(\mathrm{n}=3)$.

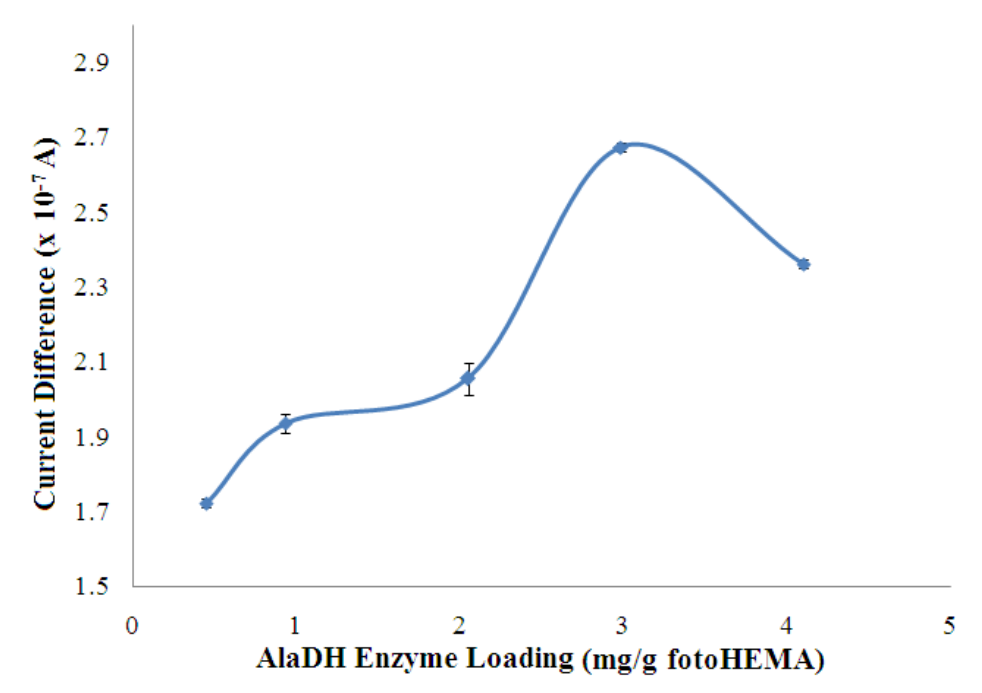

Typically, the rate of the enzymatic reaction is directly proportional to the enzyme loading. There are several conditions under which this proportionality may not occur. When large amounts of enzyme are used the added cofactor NADH may bind to the enzyme and not be available for reaction [29]. High enzyme loading also results in the blocking of the enzyme active sites, especially for enzyme that is located far from the surface of the membrane, thus making some of the enzyme not participate in enzymatic reactions. Furthermore, excessive loading of enzyme will also create a diffusion barrier to the movement of substrates and reaction products, which will also reduce the response obtained. Thus, the optimised enzyme loading of $2.98 \mathrm{mg} / \mathrm{g}$ photoHEMA was used throughout the experiments. Kwan et al. [30] have reported using the same enzyme entrapped by a poly(carbamoyl) sulfonate hydrogel on a Teflon membrane for amperometric determination of alanine. The backward enzyme reaction involved specific dehydrogenation of alanine that consumed $\mathrm{NAD}^{+}$. The reaction products, pyruvate and $\mathrm{NADH}$ were used to initiate the two other reactions that follow, which involved salicylate hydroxylase and pyruvate oxidase [30].

\subsubsection{Optimisation of Membrane Thickness for Biosensor Fabrication}

The effect of the thickness of photoHEMA membranes containing $2.98 \mathrm{mg} \mathrm{AlaDH} / \mathrm{g}$ photo HEMA on the biosensor response is presented in Figure 6. The optimum thickness of AlaDH enzyme-containing photoHEMA membrane was found to be $0.18 \mathrm{~mm}$ because of the consistent high 
signal attained for the same $\mathrm{NH}_{4}{ }^{+}$ion concentration ( $\mathrm{RSD}=5.6 \%$ ). A membrane thickness of $0.15 \mathrm{~mm}$ gave a slightly lower response due to the low reproducibility of preparing a thin membrane $(\mathrm{RSD}=14.2 \%)$. Moreover, a thin membrane may lead to the leaching out of the immobilized enzyme. Thicker membranes, between $0.22-0.26 \mathrm{~mm}$, gave inconsistently low responses as these membranes resulted in the active sites of the enzyme becoming less accessible, in addition to hindering the diffusion of rectants and products.

Figure 6. Effect of membrane thickness on the biosensor response in a solution containing $100 \mathrm{mM} \mathrm{NH}_{4}{ }^{+}$ion at $\mathrm{pH} 7(\mathrm{n}=3)$.

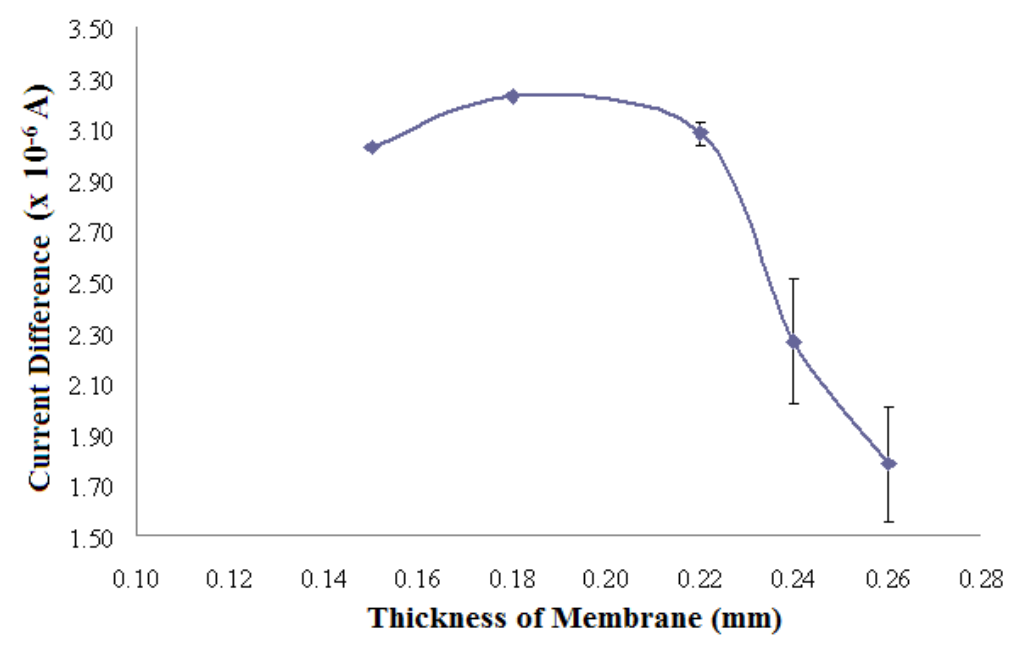

\subsubsection{Optimisation of Temperature of Biosensor Operation}

The biosensor response increased rapidly with temperature and reached a maximum at the temperature of $35^{\circ} \mathrm{C}$ (Figure 7). This is explained by the increase in the rate of an enzyme reaction with increasing temperature [29].

Figure 7. The temperature effect on the response of the $\mathrm{NH}_{4}{ }^{+}$ion biosensor in a solution containing $100 \mathrm{mM} \mathrm{NH}_{4}{ }^{+}$ion at $\mathrm{pH} 7(\mathrm{n}=3)$. The biosensors were prepared one day before and stored at $4{ }^{\circ} \mathrm{C}$ before testing at various temperatures.

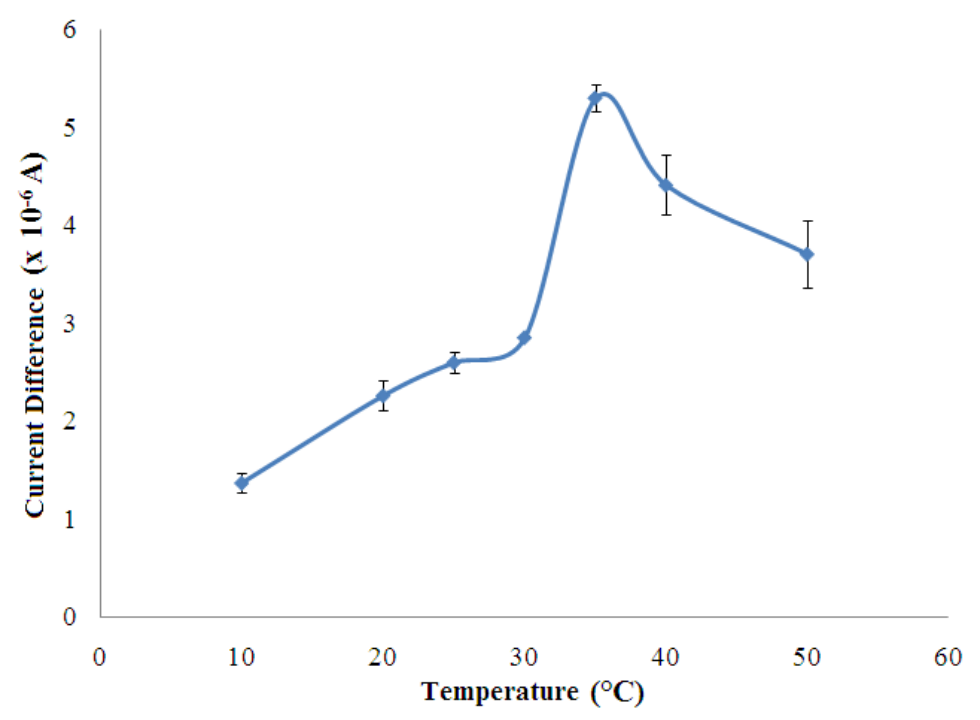


However, the biosensor response decreased when the temperature increased above $35^{\circ} \mathrm{C}$. In this state, the denaturation of the enzyme occurs where the weak bonding such as hydrogen and ionic bonds are broken at high temperatures [31]. In the present work, $25{ }^{\circ} \mathrm{C}$ was chosen as working temperature for all subsequent experiments since the sensitivity of the biosensors were sufficiently good for further studies.

\subsubsection{Optimisation of Loading for Pyruvate and NADH}

The concentrations of both pyruvate and $\mathrm{NADH}$, which were immobilized in the pHEMA membrane were optimized to yield the best biosensor response to $\mathrm{NH}_{4}{ }^{+}$ion. The results are shown in Figures 8 and 9, which indicate that the current response increases with increasing pyruvate and NADH loadings and becomes saturated at loadings of $42.99 \mathrm{mg}$ pyruvate/g pHEMA and $160.87 \mathrm{mg}$ $\mathrm{NADH} / \mathrm{g}$ pHEMA, respectively.

Figure 8. The effect of the amount of pyruvate entrapped in a pHEMA membrane on the response of the $\mathrm{NH}_{4}{ }^{+}$ion biosensor $\left(100 \mathrm{mM} \mathrm{NH}_{4}{ }^{+}\right.$ion at $\left.\mathrm{pH} 7\right)(\mathrm{n}=3)$.

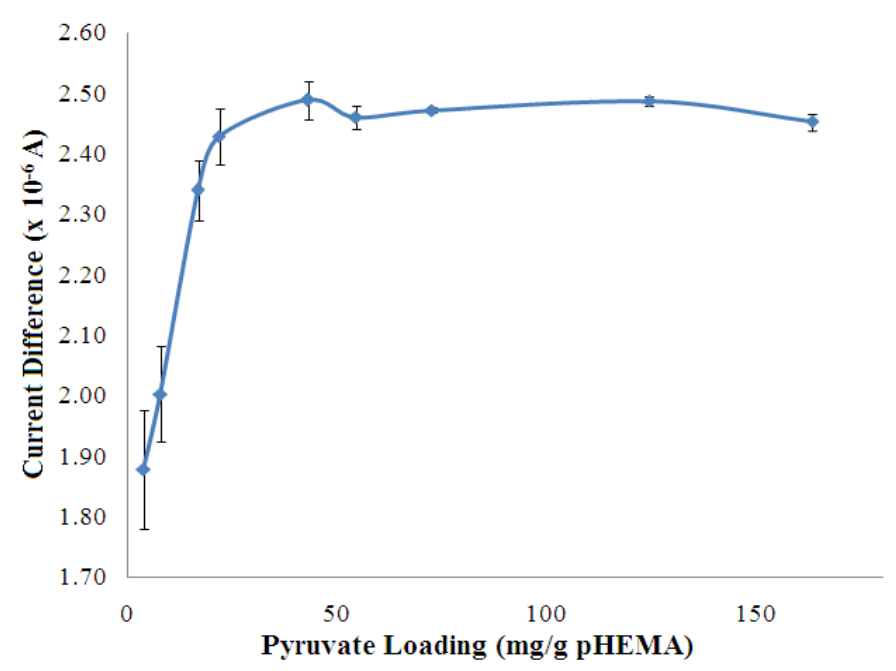

Figure 9. The response of the $\mathrm{NH}_{4}{ }^{+}$ion biosensor to various amount of NADH entrapped in a pHEMA membrane on the response of the $\mathrm{NH}_{4}{ }^{+}$ion biosensor $\left(100 \mathrm{mM} \mathrm{NH}_{4}{ }^{+}\right.$ion at $\mathrm{pH} 7)(\mathrm{n}=3)$.

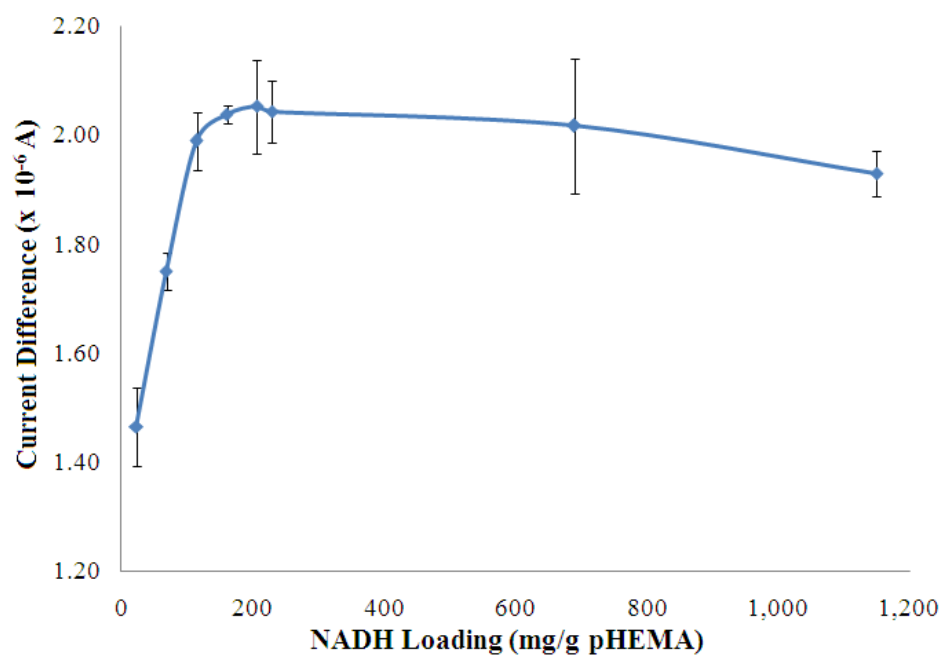




\subsection{Analytical Performance of $\mathrm{NH}_{4}^{+}$Ion Biosensor}

\subsubsection{The Response Range of Biosensor}

The response of the biosensor was examined from $10-600 \mathrm{mM}$ of $\mathrm{NH}_{4}{ }^{+}$ion and the results are shown in Figure 10.

Figure 10. The response of the biosensor towards different $\mathrm{NH}_{4}{ }^{+}$ion concentration in the range of $10-600 \mathrm{mM}$ at $\mathrm{pH} 7(\mathrm{n}=3)$.

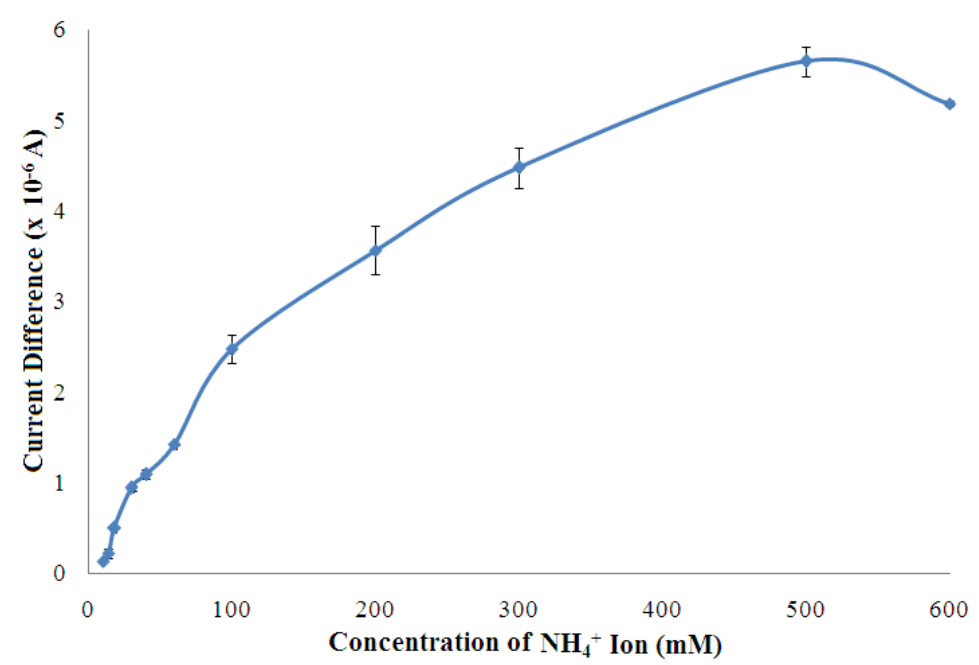

The biosensor sensor response was found increased with increasing $\mathrm{NH}_{4}^{+}$ion concentration from 10-500 mM, and reached saturation beyond $500 \mathrm{mM} \mathrm{NH}_{4}{ }^{+}$ion. This phenomenon is due to the fact that available pyruvate, cofactor $\mathrm{NADH}$, and enzyme active sites have been gradually consumed with increasing $\mathrm{NH}_{4}{ }^{+}$ion concentration until a saturation condition is achieved. Furthermore, at high levels of $\mathrm{NH}_{4}{ }^{+}$ion, the ionic strength of the reaction medium increases and thereby reduces the enzymatic reaction which is also influenced by the charge at the enzyme active sites. A linear response range was observed at $10-100 \mathrm{mM}\left(\mathrm{R}^{2}=0.978, \mathrm{n}=7\right)$ with a limit of detection of $0.18 \mathrm{mM}$. The apparent $K_{\mathrm{m}}$ value estimated from the Lineweaver-Burk plot was $34.01 \mathrm{mM}$ (Figure 11).

Figure 11. Lineweaver-Burk plots of the reagentless biosensor.

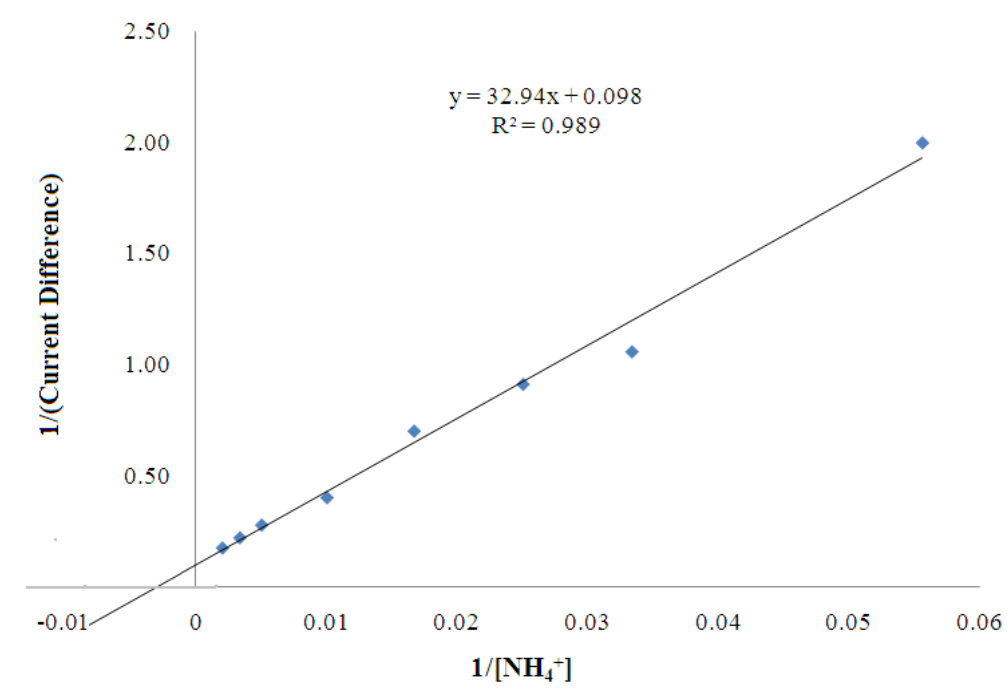




\subsubsection{The Biosensor Reproducibility and Repeatability}

The reproducibility and repeatability of the reagentless biosensor was evaluated at $30 \mathrm{mM} \mathrm{NH}_{4}^{+}$ ion. The current difference measurements obtained using different electrodes gave low RSD values from $1.4-4.9 \%(n=5)$. These values were low enough to consider that the membranes were reproducible as fabricated by the proposed method. However, the slightly higher repeatability RSD values (21.7-26.4\%, $\mathrm{n}=5$ ) obtained using the same biosensor was attributed to the irreversible oxidation of immobilized NADH at the electrode surface, which resulted in a decreasing current difference being observed for five consecutive measurements over the same electrode (Figure 12). The poor repeatability is an inherent effect from the leaching of the immobilized NADH and pyruvate. Both of these reactants are deliberately allowed to leach out from the membrane in order for them to diffuse into the enzymatic membrane to react with the AlaDH enzyme. Therefore, the poor repeatability is attributed to the loss and consumption of these reactants when the biosensor is reused many times. The biosensor is mainly used for on-site analysis and because it is made from SPE that can be manufactured at low cost, thus one can aim for a single-use and disposable electrode.

Figure 12. The reproducibility and repeatability of the reagentless $\mathrm{NH}_{4}{ }^{+}$ion biosensor that has been exposed to $30 \mathrm{mM} \mathrm{NH}_{4}{ }^{+}$ion at $\mathrm{pH} 7(\mathrm{n}=5)$.

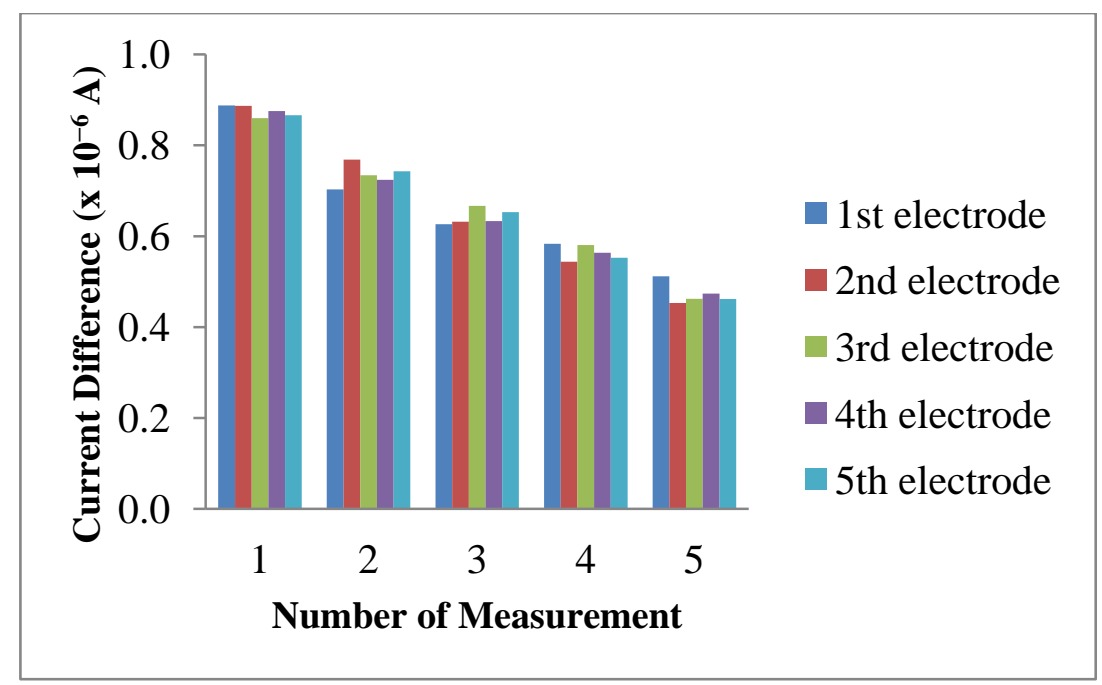

\subsubsection{Biosensor Stability}

In terms of biosensor stability, over a period of 30 days and using $30 \mathrm{mM} \mathrm{NH}_{4}{ }^{+}$ion, the reagentless biosensor first showed a decrease in sensitivity of approximately $67 \%$ during the first four days, after which the sensitivity was maintained for up to 20 days before further deterioration of the response began. After 30-day storage period, the biosensor still retained about 50\% of the initial sensitivity. (Table 1). An amperometric biosensor employing AlaDH enzyme for alanine determination reported an operational stability of only two days and the sensor response dropped to $50 \%$ of the initial sensitivity after day-13 [30]. 
Table 1. The stability of the reagentless $\mathrm{NH}_{4}^{+}$ion biosensor tested in solution containing $30 \mathrm{mM} \mathrm{NH}_{4}{ }^{+}$ion at $\mathrm{pH} 7$ over a period of 30 days $(\mathrm{n}=3)$.

\begin{tabular}{cccc}
\hline Time (day) & $\begin{array}{c}\text { Current Difference } \\
\left(\times \mathbf{1 0}^{-7} \mathbf{A}\right)\end{array}$ & $\begin{array}{c}\text { Standard } \\
\text { deviation }\end{array}$ & $\begin{array}{c}\text { Relative response } \\
(\boldsymbol{\%})\end{array}$ \\
\hline 1 & 0.9541 & 0.0695 & 100.0 \\
4 & 0.6354 & 0.0555 & 66.6 \\
19 & 0.5754 & 0.0062 & 60.3 \\
23 & 0.5099 & 0.0418 & 53.4 \\
26 & 0.4697 & 0.0059 & 49.2 \\
30 & 0.4490 & 0.0378 & 47.1 \\
\hline
\end{tabular}

\subsubsection{Effects of Interferents on Biosensor Response}

The possible interferences in the determination of $\mathrm{NH}_{4}{ }^{+}$ion by the reagentless biosensor were investigated and the results are depicted in Table 2 . The reagentless biosensor did not suffer any interference from alkali metal ions at levels occurring in natural waters [32]. But approaching a 1:1 molar ratio, interference was observed because at high concentration of ions, and high ionic strength of the measurement medium that appears to reduce the enzymatic reaction [31]. The stability of AlaDH is higher in the presence of $\mathrm{NaCl}$ salt compared to $\mathrm{KCl}$ [22], hence $\mathrm{Na}^{+}$ion did not demonstrate any observable interference when compared with $\mathrm{K}^{+}$ion, even at a molar ratio of $1: 1 . \mathrm{CH}_{3} \mathrm{NH}_{2}$ and $\mathrm{C}_{2} \mathrm{H}_{5} \mathrm{NH}_{2}$ interfered significantly at molar ratios of 0.1 and above. The interference increases the biosensor response as some physicochemical properties of amines are similar to $\mathrm{NH}_{4}^{+}$ion. However, such interference by amines is not expected in natural water samples due to their low level, usually 100 times lower than $\mathrm{NH}_{4}{ }^{+}$ion [10].

Table 2. The effect of $\mathrm{Na}^{+}, \mathrm{K}^{+}, \mathrm{CH}_{3} \mathrm{NH}_{2}$ and $\mathrm{C}_{2} \mathrm{H}_{5} \mathrm{NH}_{2}$ at different molar ratios to the response of $\mathrm{NH}_{4}{ }^{+}$ion biosensor (fixed $\mathrm{NH}_{4}{ }^{+}$at $30 \mathrm{mM} ; \mathrm{pH} 7 ; \mathrm{n}=3$ ).

\begin{tabular}{cccccc}
\hline \multirow{2}{*}{ Interferent } & \multicolumn{5}{c}{ Current difference $\left(\times \mathbf{1 0}^{-\mathbf{6}} \mathbf{A}\right)$ at different molar ratios of interferent: $\mathbf{~ N H}_{4}{ }^{+}$ion } \\
\cline { 2 - 6 } & $\mathbf{0 . 0 0 : 1}$ & $\mathbf{0 . 0 1 : 1}$ & $\mathbf{0 . 1 0 : 1}$ & $\mathbf{0 . 5 0 : 1}$ & $\mathbf{1 . 0 0 : 1}$ \\
\hline $\mathrm{Na}^{+}$ & $0.887 \pm 0.013$ & $0.850 \pm 0.033$ & $0.843 \pm 0.016$ & $0.831 \pm 0.036$ & $0.844 \pm 0.039$ \\
$\mathrm{~K}^{+}$ & $0.887 \pm 0.013$ & $0.863 \pm 0.113$ & $0.866 \pm 0.086$ & $0.901 \pm 0.049$ & $0.797 \pm 0.036 *$ \\
$\mathrm{CH}_{3} \mathrm{NH}_{2}$ & $0.887 \pm 0.013$ & $0.877 \pm 0.033$ & $1.013 \pm 0.001 *$ & $1.005 \pm 0.007 *$ & $1.778 \pm 0.061 *$ \\
$\mathrm{C}_{2} \mathrm{H}_{5} \mathrm{NH}_{2}$ & $0.887 \pm 0.013$ & $0.851 \pm 0.042$ & $0.825 \pm 0.024 *$ & $1.114 \pm 0.017 *$ & $1.599 \pm 0.110 *$ \\
\hline
\end{tabular}

$* t$ value $>t$ critical value at $95 \%$ confident level with 4 degrees of freedom.

\subsubsection{Performance of Biosensor for Water Sample Analysis}

To assess the accuracy of the biosensor, recovery studies were performed using river water samples which had been spiked with known $\mathrm{NH}_{4}{ }^{+}$ion concentrations within the linear response range of the biosensor. The results are shown in Table 3. The recovery values obtained were close to $100 \%$ in the five different $\mathrm{NH}_{4}{ }^{+}$ion concentrations spiked into river water samples. The analytical performance of the reagentless biosensor for water analysis was compared with the standard method of Nessler method using spectrophotometric method. The $t$-test applied to examine whether the two methods gave results 
that both methods were not statistically different for $\mathrm{NH}_{4}{ }^{+}$ion determination. This indicates that the reagentless biosensor can be used for $\mathrm{NH}_{4}{ }^{+}$ion determination.

Table 3. A comparative study of the reagentless biosensor and Nessler method for $\mathrm{NH}_{4}{ }^{+}$ ion analysis in different river water samples containing spiked $\mathrm{NH}_{4}{ }^{+}$ion concentrations from $10-30 \mathrm{mM}$.

\begin{tabular}{ccccc}
\hline Sample & $\begin{array}{c}\text { Concentration of } \\
\mathbf{N H}_{\mathbf{4}}{ }^{+} \text {ion spiked in } \\
\text { each sample }(\mathbf{m M})\end{array}$ & $\begin{array}{c}\text { Concentration of } \mathbf{N H}_{\mathbf{4}}{ }^{+} \text {ion } \\
\text { determined by biosensor } \\
(\mathbf{n = 3}),(\mathbf{m M})\end{array}$ & $\begin{array}{c}\text { Concentration of } \\
\mathbf{N H}_{\mathbf{4}}{ }^{+} \text {ion by Nessler } \\
\text { method } \mathbf{( n = 3 ) , ~} \mathbf{~ M M}\end{array}$ & $\begin{array}{c}\text { Recovery } \\
(\boldsymbol{\%})\end{array}$ \\
\hline Sample 1 & 10.00 & $10.29 \pm 0.95$ & $10.41 \pm 0.79$ & 102.9 \\
Sample 2 & 18.00 & $18.63 \pm 1.05$ & $18.20 \pm 0.91$ & 103.5 \\
Sample 3 & 22.00 & $21.56 \pm 1.52$ & $21.90 \pm 0.76$ & 98.0 \\
Sample 4 & 26.00 & $26.13 \pm 0.32$ & $26.10 \pm 0.15$ & 100.5 \\
Sample 5 & 30.00 & $29.01 \pm 2.33$ & $30.38 \pm 1.20$ & 96.7 \\
\hline
\end{tabular}

\subsubsection{Comparison with Similar Biosensors}

Amperometric based enzymic biosensors for $\mathrm{NH}_{4}{ }^{+}$ion determination using GLDH enzyme are commonly reported in the literature [17-19] (Table 4), however, they all require that the substrates involved in the enzymic reaction with GLDH enzyme, be introduced into the assay solutions. The linear detection ranges of $\mathrm{NH}_{4}{ }^{+}$ion for biosensors using GLDH were somehow narrower compared to the use of AlaDH enzyme. The GLDH enzyme system has also been used for the optical detection of $\mathrm{NH}_{4}{ }^{+}$ion in water samples at $\mu \mathrm{M}$ level based on NADH oxidation [33]. A chitosan matrix was used for the immobilization of GLDH enzyme on a supporting glass slide but this optical biosensor system for $\mathrm{NH}_{4}^{+}$ion determination suffered interference from other possible cations present in the water samples.

Table 4. The comparison between reagentless $\mathrm{NH}_{4}{ }^{+}$biosensor and reported amperometric $\mathrm{NH}_{4}{ }^{+}$biosensor.

\begin{tabular}{ccccc}
\hline Parameters & Present study & $\begin{array}{c}\text { Abass } \text { et al. } \\
{[\mathbf{1 7 ]}}\end{array}$ & $\begin{array}{c}\text { Bertocchi } \text { et al. } \\
{[\mathbf{1 8}]}\end{array}$ & $\begin{array}{c}\text { Kwan } \text { et al. } \\
{[19]}\end{array}$ \\
\hline Enzyme & AlaDH & GLDH & GLDH & GLDH \& \\
glutamate oxidase \\
Dynamic linear range $(\mathrm{mM})$ & $10-100$ & $0.0017-0.25$ & $0.01-0.3$ & $0.01-0.30$ \\
Detection limit $(\mathrm{mM})$ & 0.18 & 0.0017 & 0.01 & 0.002 \\
Response time $(\mathrm{min})$ & $<3$ & - & - & 4 \\
\hline
\end{tabular}

\section{Conclusions}

A new reagentless amperometric biosensor for the determination of $\mathrm{NH}_{4}{ }^{+}$ions based on the enzyme AlaDH and involving the use of a stacked membrane system for the immobilization of all reagents was successfully developed. The use of a layer of low molecular weight pHEMA for NADH and pyruvate immobilization and a photocured photoHEMA membrane with entrapped AlaDH enzyme offers a simple and rapid biosensor fabrication procedure in addition to convenient $\mathrm{NH}_{4}^{+}$ion analysis, 
particularly for performing on-site analysis without the need of any addition of reagents. The reagentless biosensor demonstrated a wide linear response range between 10-100 $\mathrm{mM} \mathrm{NH}_{4}{ }^{+}$ion with a detection limit of $0.18 \mathrm{mM}$ and good selectivity over some major cations. Such a biosensor has a potential to overcome the problem of on-site analysis of $\mathrm{NH}_{4}{ }^{+}$ion because it can be used for sewage $\mathrm{NH}_{4}{ }^{+}$ion analysis without further dilution $\left(\mathrm{NH}_{4}{ }^{+}\right.$ion concentrations of sewage are typically from $65-170 \mathrm{mM})$.

\section{Acknowledgements}

We gratefully acknowledged Universiti Kebangsaan Malaysia for a research operation grant (UKM-OUP-NBT-29-151/2011) and a Postgraduate Fellowship awarded to Tan Ling Ling.

\section{References}

1. Kuo, C.T.; Wang, P.Y.; Wu, C.H. Fluorometric determination of ammonium ion by ion chromatography using postcolumn derivatization with o-phthaldialdehyde. J. Chromatogr. A 2005, 1085, 91-97.

2. Martinez, Y.M.; Hernandez, R.H.; Falco, P.C. Improved detection limit for ammonium/ammonia achieved by Berhelot's reaction by use of solid-phase extraction coupled to diffuse reflectance spectroscopy. Anal. Chim. Acta 2005, 534, 327-334.

3. Thomas, D.H.; Rey, M.; Jackson, P.E. Determination of inorganic cations and ammonium in environmental waters by ion chromatography with a high-capacity cation-exchange column. J. Chromatogr. A 2002, 956, 181-186.

4. Deyhimi, F.; Choobar, B.G. Potentiometric determination of activity coefficients for $\mathrm{NH}_{4} \mathrm{Cl}$ in the ternary $\mathrm{NH}_{4} \mathrm{Cl} / \mathrm{LiCl} / \mathrm{H}_{2} \mathrm{O}$ mixed electrolyte system. J. Electroanal. Chem. 2005, 584, 141-146.

5. Hassan, S.S.M.; Marei, S.A.; Badr, I.H.; Arida, H.A. Novel solid-state ammonium ion potentiometric sensor based on zirconium titanium phosphate ion exchanger. Anal. Chim. Acta 2001, 427, 21-28.

6. Andrew, K.N.; Worsfold, P.J.; Comber, M. On-line flow injection monitoring of ammonia in industrial liquid effluents. Anal. Chim. Acta 1995, 314, 33-43.

7. Aminot, A.; Kerouel, R.; Birot, D. A flow injection-fluorometri method for the determination of ammonium in fresh and saline waters with a view to in situ analyses. Wat. Res. 2001, 35, 1777-1785.

8. Haghighi, B.; Kurd, S.F. Sequential flow injection analysis of ammonium and nitrate using gas phase molecular absorption spectrometry. Talanta 2004, 64, 688-694.

9. Kerouel, R.; Aminot, A. Fluorometric determination of ammonia in sea and estuarine waters by direct segmented flow analysis. Mar. Chem. 1997, 57, 265-275.

10. Oliveira, S.M.; Lopes, T.I.M.S.; Toth, I.V.; Rangel, A.O.S.S. A multi-commuted flow injection system with a multi-channel propulsion unit placed before detection: Spectrophotometric determination of ammonium. Anal. Chim. Acta 2007, 600, 29-34.

11. Staden, J.F.V.; Taljaard, R.E. Determination of ammonia in water and industrial effluent streams with the indophenol blue method using sequential injection analysis. Anal. Chim. Acta 1997, 344, 281-289. 
12. Mori, M.; Tanaka, K.; Helaleh, M.I.H.; Xu, Q.; Ikedo, M.; Ogura, Y.; Sato, S.; Hu, W.; Hasebe, K. Selective determination of ammonium ios by high-speed ion-exclusion chromatography on a weakly baic anion-exchange resin column. J. Chromatogr. A 2003, 997, 191-197.

13. Kazanskaya, N.; Kukhtin, A.; Manenkova, M. FET-based sensors with robust photosensitive polymer membranes for determination of ammonium ion and urea. Biosens. Bioelectron. 1996, $11,253-261$.

14. Senillou, A.; Renault, N.J.; Griffe, C.M.F. A miniaturized ammonium sensor based on the integration of both ammonium and reference FETs in a sungle chip. Mater. Sci. Eng. C 1998, 6, 59-63.

15. Dubas, S.T.; Pimpan, V. Green synthesis of silver nanoparticles for ammonia sensing. Talanta 2008, 76, 29-33.

16. Li, P.Q.; Zhang, J.Z.; Millero, F.J.; Hansell, D.A. Continuous colorimetric determination of trace ammonium in seawater with a long-path liquid waveguide capillary cell. Mar. Chem. 2005, 107, 73-85.

17. Abass, A.K.; Hart, J.P.; Cowell, D.C.; Chappell, A. Development of an amperometric assay for $\mathrm{NH}_{4}{ }^{+}$based on a chemically modified screen-printed NADH sensor. Anal. Chim. Acta 1998, $373,1-8$.

18. Bertocchi, P.; Compagnone, D. Amperometric ammonium ion and urea determination with enzyme-based probes. Biosens. Bioelectron. 1996, 11, 1-10.

19. Kwan, R.C.H.; Hon, P.Y.T.; Renneberg, R. Amperometric determination of ammonium with bienzyme/poly (carbamoyl) sulfonate hydrogel-based biosensor. Sens. Actuat. B 2005, 107, 616-622.

20. Agren, D.; Stehr, M.; Berthold, C.L.; Kapoor, S.; Oehlmann, W.; Singh, M.; Schneider, G. Three-dimensional structures of apo- and hoho-L-alanine dehydrogenase from mycobacterium tuberculosis reveal conformational changes upon coenzyme binding. J. Mol. Biol. 2008, 377, 1161-1173.

21. Hashimoto, S.I.; Katsumata, R. L-alanine fermentation by an alanine racemase-deficient mutant of the DL-alanine hyperproducing bacterium Arthrobacter oxydans HAP-1. J. Ferment. Bioeng. 1998, 86, 385-390.

22. Kato, S.I.; Ohshima, T.; Galkin, A.; Kulakova, L.; Yoshimura, T.; Esaki, N. Purification and characterization of alanine dehydrogenase from a marine bacterium, vibrio proteolyticus. J. Mol. Catal. Part B 2003, 23, 373-378.

23. Ohashima, T.; Soda, K. Purification and properties of alanine dehydrogenase from Bacillus spharicus. Eur. J. Biochem. 1979, 100, 29-39.

24. Nassef, H.M.; Radi, A.E.; Sullivan, C.K.O. Electrocatalytic sensing of NADH on a glassy carbon electrode modified with electrografted o-aminophenol film. Electrochem. Commun. 2006, 8, 1719-1725.

25. Behera, S.; Retna, C.R. Mediatorless voltammetric oxidation of NADH and sensing of ethanol. Biosens. Bioelectron. 2007, 21, 949-956.

26. Retna, C.R.; Behera, S. Self-assembled monolayers of thio-substituted nucleobases on gold electrode for the electroanalysis of NADH, ethanol and uric acid. Sens. Actuat. B 2005, 128, 31-38. 
27. Rao, T.N.; Yagi, I.; Miwa, T.; Tryk, D.A.; Fujishima, A. Electrochemical oxidation of NADH at highly boron-doped diamond electrodes. Anal. Chem. 1999, 71, 2506-2511.

28. Schroder, I.; Vadas, A.; Johnson, E.; Lim, S.; Monbouquette, H.G. A novel archeal alanine dehydrogenase homologous to ornithine cyclodeaminase and $\mu$-crystalin. J. Bacteriol. 2004, 186, 7680-7689.

29. Carr, P.W.; Bowers, L.D. Immobilised Enzymes in Analytical and Clinical Chemistry; John Wiley \& Sons: New York, NY, USA, 1980.

30. Kwan, R.C.H.; Hon, P.Y.T.; Renneberg, R. Amperometric biosensor for rapid determination of alanine. Anal. Chim. Acta 2004, 523, 81-88.

31. Renkema, J.M.S.; Gruppen, H.; Vliet, T.V. Influence of $\mathrm{pH}$ and ionic strength on heat-induced formation and rheological properties of soy protein gels in relation to denaturation and their protein compositions. J. Agric. Food Chem. 2002, 50, 6064-6071.

32. Carville, M.; Robinson, H. Leachate treatment. Available online: http://www.leachate-treatment.com (accessed on 14 July 2011).

33. Nur Ellina, A.; Jaafar, A.; Musa, A.; Heng, L.Y.; Hamidah, S.; Nadarajah, K. Biosensor based on glutamate dehydrogenase immobilized in chitosan for the determination of ammonium in water samples. Anal. Biochem. 2009, 388, 28-32.

(C) 2011 by the authors; licensee MDPI, Basel, Switzerland. This article is an open access article distributed under the terms and conditions of the Creative Commons Attribution license (http://creativecommons.org/licenses/by/3.0/). 